Heinz Faßmann

\title{
Leadership Talk by the Austrian Federal Minister for Education, Science and Research (2018-2019)
}

It has been an honour to speak at the conference, “An End to Antisemitism!" There cannot be enough words of thanks to the European Jewish Congress and the Jewish Community in Vienna, especially Dr. Moshe Kantor and Dr. Muzicant for organizing this conference in Vienna. The academic partners Tel Aviv University, New York University, and the University of Vienna have designed an excellent multi-day program with eminent speakers.

Especially in 2018, the year of commemoration in which we remember the eightieth anniversary of the take-over of power by the National Socialists in Austria, the so-called "Anschluss," this conference is so important because of our special duty to fight against any form of antisemitism that we can still observe in our society today.

\section{Personal Experience}

Denying historical co-responsibility was the dominant way of thinking in postwar Austria. It took many decades and it was Franz Vranitzky, and after him many other politicians, who clearly stated that Austria had, on the one hand, been a victim but, on the other hand, that also way too many Austrians had become perpetrators. ${ }^{1}$ Antisemitism was not a new phenomenon at the time, rather it was deeply rooted in Austrian history and society.

We have to learn from historic events, and we have to fight against antisemitism at its roots. Not only do we have a historic responsibility, but we also have to live up to that responsibility every day.

Today, the new government of Austria is very much committed to the fight against antisemitism in Europe and everywhere else. There is zero tolerance for any form of antisemitism.

1 Cf. C. Zöchling, "Auschwitz: Jahrelang präsentierte sich Österreich als 'Erstes Opfer der Nazis', Profil, October 31, 2013, https://www.profil.at/oesterreich/history/auschwitz-jahrelangoesterreich-erstes-opfer-nazis-368762.

Ә OpenAccess. () 2019 Heinz Faßmann, published by De Gruyter. (cc) BY-NC-ND This work is licensed under the Creative Commons Attribution-NonCommercial-NoDerivatives 4.0 License. 
This is also why a conference against antisemitism in Vienna is very important and timely in order to raise awareness.

\section{New Forms of Antisemitism}

In the past decades, new forms of antisemitism have surged. One of them is the disproportional criticism of Israel, as described in IHRA's working definition of antisemitism. ${ }^{2}$ Another highly disturbing form of antisemitism manifests itself among migrants in Europe and Austria, unfortunately also, but not limited to migrants from Muslim societies. With the current refugee crisis in Europe, we face numerous challenges in this context. There is also a considerable number of migrants who have not been raised in liberal societies and have little respect and knowledge for the values of democracy. Together with antisemitic traditions, this fact produces a dangerous mix. This has been and will therefore be an important part of our integration efforts with courses on our values for refugees as well as raising awareness in kindergartens and schools.

I recommended these measures when I was Chair of the Expert Group on Integration, and I received a lot of criticism for suggesting them. The dominant opinion was that values cannot be built with education. I do not agree with this opinion, we have to communicate clearly what the basic values of our Republic are and the rejection of antisemitism is one of them. And of course, also we who bear responsibility for the country, and our society have to live up to these standards and will not accept any double standards for migrants or for autochthonous Austrians.

\section{The Role of Education}

Let me emphasize another question: What can we do against the rise of antisemitism. My answer is: Education-adequate information and intelligent learning tools as an instrument.

At the Ministry of Education there are many activities to keep history relevant._erinnern.at_, the Holocaust Education Institute of my Ministry provides

2 Cf. "Working Definition of Antisemitism," International Holocaust Remembrance Alliance, issued May 26, 2016, accessed July 2, 2018, https://www.holocaustremembrance.com/news-ar chive/working-definition-antisemitism. 
an important program to support teaching and learning the lessons about the Holocaust.

For the last twenty years, _erinnern.at_ has provided sustainable seminars on teaching and learning about the Holocaust in close cooperation with Yad Vashem. ${ }^{3}$ And if it would be possible, it would be my sincere wish to enable every teacher in Austria to attend this training course once in his or her professional career. Until now, we have subsidized the participation of nearly seven hundred teachers at these annual in-service trainings.

The preservation of the life stories of survivors of the Shoah, as a legacy for our young people, is another core element of our pedagogical endeavors. The commemoration year 2018 marks the realization of a comprehensive online database with a collection of Austrian-related survivors' testimonies by the Ministry of Education and Science and_erinnern.at_and we are a leading partner in "Stories that Move," a large innovative European online platform against racism and antisemitism. ${ }^{4}$

I also would like to point out that Austria is fully committed to the vision and mission of the International Holocaust Remembrance Alliance and its Working Definition of Antisemitism which the Austrian government has adopted last year. ${ }^{5}$

Education is a key element in order to prevent new generations from repeating the failures of the past. We will therefore continue to foster a culture of commemoration in our schools.

\section{The Bilateral Relations between Austria and Israel}

As my last point, I would like to mention the bilateral relations to Israel.

Austria and Israel have had excellent bilateral relations. Not only on the political sphere, but also tourism between Austria and Israel is at an all-time high, and we have developed excellent and increasing economic relations.

We will support Israel if it should decide to run for the UN Security Council.

3 Cf. http://www.erinnern.at/bundeslaender/oesterreich/zu-erinnern-at, accessed July 2, 2018.

4 Cf. https://www.storiesthatmove.org/de/startseite/, accessed July 2, 2018.

5 Austria has adopted the Working Definition of Antisemitism on April 25, 2017. Cf. IHRA, "Austrian Government Adopts Working Definition of Antisemitism," April 28, 2017, https://www. holocaustremembrance.com/news-archive/austrian-government-adopts-working-definition-anti semitism; N.N., "Ministerrat beschloss Antisemitismus-Definition," ORF, April 25, 2017, https:// orf.at/v2/stories/2388793. 
We also have a clear pro-Israel government-program. For the first time, there is a clear commitment to Israel as a Jewish state; we will also introduce new legislation within the coming years to grant citizenship to descendants of Nazivictims.

And, we are not naive when it comes to the Middle East and the role of Iran and its growing influence on the region. This is a concern for Israel, but it's also a matter of concern for Europe.

\section{Conclusion}

To conclude, I would like to say that I have been to Israel twice and I was so impressed by the achievements of the Israeli people. Excellent infrastructure, excellent universities higher ranked than my alma mater, and a strong economy. The country celebrates its seventieth anniversary and it can be proud of it.

As Vice-Rector at the University of Vienna, I have established the first strategic partnership with the Hebrew University and due to competence and the enthusiasm of the professors, the partnership is now flourishing. It has always been a highlight for me to welcome twenty-five students from the Hebrew University-together with Her Excellency Ambassador Lador Fresher and Governor Nowotny-who will stay in Vienna for some weeks and in many cases discover the hometown of their grandparents or grand-grandparents.

I wish to convey my regards to this conference and its participants and hope that the theme of the conference "An End to Antisemitism!" will eventually become reality.

Heinz Faßmann is Professor of human geography and land-use planning at the University of Vienna. Between 2011 and 2015, he has served as vice-rector for human resources development and international relations at the University of Vienna. From 2015 to 2017 he has been vice-rector for research and international affairs. Faßmann routinely acted as a political consultant and advisor to the Austrian government. From 2018 until 2019, he has served as Austrian Federal Minister of Education, Science and Research.

\section{Bibliography}

_erinnern.at_. "Kurzbeschreibung." Accessed July 2, 2018. http://www.erinnern.at/bunde slaender/oesterreich/zu-erinnern-at. 
International Holocaust Remembrance Alliance. "Austrian Government Adopts Working Definition of Antisemitism.” Issued April 28, 2017, accessed July 2, 2018. https://www. holocaustremembrance.com/news-archive/austrian-government-adopts-working-defi nition-antisemitism

International Holocaust Remembrance Alliance. "Working Definition of Antisemitism." Issued May 26, 2016, accessed July 2, 2018. https://www.holocaustremembrance.com/news-ar chive/working-definition-antisemitism.

N.N. "Ministerrat beschloss Antisemitismus-Definition.” ORF, April 25, 2017. https://orf.at/v2/ stories/ 2388793.

Stories that Move. "Toolbox gegen Diskriminierung." Accessed July 2, 2018. https://www.stor iesthatmove.org/de/startseite/.

Zöchling, Christa. "Auschwitz: Jahrelang präsentierte sich Österreich als 'Erstes Opfer der Nazis'." Profil, October 31, 2013. https://www.profil.at/oesterreich/history/auschwitz-jah relang-oesterreich-erstes-opfer-nazis-368762. 
